\title{
Editorial
}

\section{From schlock to hot: Shifting perceptions of Brooklyn}

Place Branding and Public Diplomacy (2007) 3, 263-267. doi:10.1057/palgrave.pb.6000078

\section{PREFACE}

This special issue of Place Branding and Public Diplomacy looks at culture and its impact on place brands. Throughout the issue, we are reminded that places and place brands are inherently different from products and product brands and that conventional branding models and approaches are insufficient. Viewed through the lens of culture, in its many meanings and manifestations, place branding takes on new complexity. The contributing authors have approached the subject from a wide range of perspectives and contexts. John Holden is inspired by Istanbul in his look at the creative city construct shedding light on the importance of emergent meaning and the idea that exciting brand experience happens in real time - in the here and now. Emergent meaning is just as relevant to 'Main Street' USA in Pryor and Grossbart's research into how social actors co-create place brands. Bianchini and Ghilardi present an alternative, culturally sensitive approach to place branding with a plea for policy makers to work holistically and collaboratively with experts beyond the boundaries of their own discipline. Wayne Hemingway takes us on a personal and practical journey through his view on culture's role in branding places and its influence on his work in designing socially significant neighbourhoods in the UK. The arts are addressed in Peel and Lloyd's look at
Antony Gormley's public art on a British beach and the role of public policy and the democratic process, while Hornskov examines the joint Swedish Danish Øresund Region brand initiative and an arts community's resistance to giving over its identity to a hybrid regional identity. The complexity of culture, identity and nationhood are discussed by Skinner and Kubacki, and culture as a mechanism for regenerating cities is explored in the following case study of the rebranding of Brooklyn, NY. We had many interesting submissions, far more than we are able to publish in this issue, Two of these, Trueman, Cook and Cornelius' look at the role of culture in the regeneration of Bradford, England and Singleton and McKenzie's examination of culture and the built environment in Western Australia, will be published in the next issue (Vol.4, No.1). I hope the contributions find resonance with readers and serve to deepen our understanding of culture and its role in branding our cities, regions and nations.

\section{PLACE BRANDING AND THE CULTURE TOOL}

Increasingly, culture and the arts are being used as key components of place marketing campaigns and also of urban development and regeneration programmes. The arts are generally seen as positive and attractive features of a city. The world's greatest cities are home to most of the world's greatest 
arts and cultural institutions. What would London be without Covent Garden, Paris without the Louvre or New York without the Metropolitan Opera or the Museum of Modern Art? Smaller and less prosperous cities, too, have joined the culture bandwagon and have revived their localities with big name art: the

Guggenheim brands Bilbao and the Tate brands St Ives.

Iconic cultural institutions provide benefits that can be measured in economic terms, namely jobs, visitors and their spend. They are also key features of a positive city brand image and, as such, they provide benefits that are difficult, if not impossible, to measure by conventional economic means. They improve quality of life, enhance the city experience, display prosperity, sophistication and democratic values, inspire civic pride, garner attention and capture the imagination. Too often, we look for economic returns from our cultural institutions when their value to our cities is indeed far greater.

It is not just the great cultural institutions that contribute to creating positive city brand images. Community arts organisations, artist communities, individual artists and the creative industries play equally important roles in developing positive perceptions of cities. In many ways, they play a greater role in revitalising cities than mainstream arts organisations affected by ageing and dwindling audiences. Their social and economic impact, however, is more subtle, more complex and far more difficult to isolate, understand and duplicate. Defining their economic value becomes little more than an exercise in creative accounting to translate the value of intangible benefits into numbers on a page.

Despite this difficulty, culture is being used as a tool for urban regeneration. The assumption is that cities that develop an environment in which the arts and creative businesses can flourish will benefit from a positive place brand. Successes and failures abound, but there appears to be little understanding of why what works for one city does not work for another, or indeed how culture works in the context of place branding.

\section{PLACE BRANDING IS IN OUR MINDS}

Academics and practitioners have been reaching an understanding of place branding for well over a decade. There are no simple definitions, but rather many useful concepts that serve to guide us through a labyrinth of complexity. Central to understanding place branding is the idea that brands exist in the minds of consumers (De Chernatony, 1992). We create the brand in our minds. Branding is comprised of emotional, intellectual, psychological and physical aspects and place branding is an extension of this to the physical and social environment of place (Kavaratzis and Ashworth, unpublished).

Applying principles of corporate identity to places with logos, straplines, messages and promotional campaigns is place marketing. Place branding, on the other hand, is concerned with the pre-existing reputation, or the context within which marketing communications operate. To say that changing this context, this 'constantly fluctuating group consciousness', is complex is an understatement. We have very little influence over the millions of individuals who essentially create and own the brand (Anholt, 2005: 225).

Images of place are derived from a range of cultural, social, environmental, political, economic and location factors. 'New York is a series of images of New York. It's that sense of walking down the street with all those tall buildings all those lights' (Steigerwald citing Kotkin, 2003). People construct a city's brand image out of an array of features, advantages and benefits that they collect about the city and hold in their minds. In addition to first-hand experience, people receive information via the media, film, television, literature, text books, computer games, the internet and word of mouth. Some of this information will be created, selected and communicated by place marketers trying to reposition the city, but most of it will be serving a vast and uncoordinated array of other agendas. There is tremendous potential for mixed messages.

If we agree with Rem Koolhaas (as cited in Speaks, 2002) that cities are self-organising 
urban life forms that have outstripped any means of conventional organisation or control, then we can grasp the complexity of how cities communicate. Just as cities grow organically and, indeed, chaotically through a network system so do communications about them and our images of them. Cities face a particular dilemma when implementing brand strategy. Not only do they have little control over how consumers build perceptions of place, they also have low levels of control over the activities happening within them that impact on the brand (Parkerson and Saunders, 2005).

Places are marketed within this context. It is the place marketer's job to understand what features give a city its image and then to choose and orchestrate the critical advantages (the ones people care about) that work together to move the city into a useful place in people's minds. But the marketer needs a great place to market. It is the place maker's job to develop the right policies, to inspire 'on brand' decision making and ensure that the marketer has a great place to market. Who are a city's place makers? City leaders, politicians, local authorities, development agencies, policy makers, city planners, leaders of key institutions and business and community leaders are some of the people who can inspire and influence decisions that improve or damage a city brand image. There are likely to be many more.

\section{WHO WOULDA THUNK IT - THE CITY OF BROOKLYN!}

The arts and culture played a central role in repositioning Brooklyn, NY, from a 'schlocky' place to do business to NYC's hottest borough. Brooklyn is one of New York City's five boroughs and has existed very much in the shadow of Manhattan since it merged with New York City in 1898 and since its decline post WWII when the middle class left the city in pursuit of the American Dream in the suburbs. Downtown Brooklyn developed a reputation for doing 'schlocky business' and was considered a dead neighbourhood. In the 1980s, there was a property boom in Manhattan, causing an exodus of businesses to the surrounding areas. The New York City Economic Development Corporation (NYCEDC) embarked on multi-level marketing of the city, which included marketing the boroughs as secondary places to do business. They 'sold' NYC as a premium business location, differentiating the boroughs as being less expensive, but easily accessible to and having all the amenities and advantages of Manhattan.

Manhattan's property boom also forced artists out of the city. They were the first group to move out to Brooklyn looking for lower rents. They were followed by home buyers unable to afford property in Manhattan, but who wanted to stay in the area and were attracted by Brooklyn's excellent housing stock.

This phenomenon laid the foundation for what Jeanne Lutfy, former President of the Brooklyn Academy of Music - Local Development Corporation (BAMLDC),${ }^{1}$ called 'the big surge'. It was recognised that artists were moving to Brooklyn and that this phenomenon could be used to reposition the borough. Choosing a location with excellent transportation links and a history of entertainment and the arts through the Brooklyn Academy of Music, the city established The Cultural District, which in turn attracted world-renowned arts groups (Lutfy, 2005).

Architects Rem Koolhaas and Diller Scofidio + Renfro were brought in to produce the masterplan for the district. The aim was to encourage organic, as opposed to planned, development with a 'series of building recommendations for a network of systems and spaces, which maximise the interplay between the various cultural institutions and make the artistic aspect more visible'. Concerns of gentrification of the area that would displace the existing local character and ultimately outprice the artist community were addressed through consultation and creative use of the city's planning powers. This resulted in policy ensuring space for local arts groups and an increase in the percentage of affordable housing (CABE, 2007). 
The Cultural District is but one layer of a multi-layered approach to changing perceptions of Brooklyn. Other layers include the revitalisation of neighbourhoods, the Brooklyn Bridge Park, a major sports arena, a business district and a retail target. Each layer mutually supports and builds upon the other helping to develop infrastructure, attract diverse people and businesses to the borough and create a unique offering for new and old residents alike.

Brooklyn's brand development is described as a confluence of actions and circumstances, some of which are well outside of anyone's control, that reinforce activity and change perceptions (Lutfy, 2005).

Since the 1980s, perceptions of Brooklyn have changed. It is now the 'hot' borough. New residents and, in particular, young people have helped to redefine the area. They do not share the stereotypical perceptions of older generations; they like the mix of rough, sophistication, newness and the arts. There is authenticity in 'schlock' that is true Brooklyn and that even the Borough President Marty Markowitz is proud to promote with billboards shouting 'FUHGEDDABOUDIT!' The Lonely Planet Guide placed Brooklyn in their top ten tourist destinations in the world for its food, culture, character and for being the 'hippest part of New York City'. 'Who woulda thunk it — the City of Brooklyn!' (Markowitz, 2007). Schlock is hot in Brooklyn.

Brooklyn has been 'rebranded' and the brand is still evolving. Brooklyn does not have a brand strategy per se. BAMLDC actively sought out brand building opportunities coordinating and leading on building the Brooklyn brand; however, not all contributors are aware of how their own decisions and activity support or undermine the brand (Lutfy, 2005). Nonetheless, the combined work of Local Development Corporations, property developers and city leaders, Brooklyn's 'place makers' if you will, is brand building. They have not built the brand with logos or a specific brand strategy. It was built firstly by being responsive to phenomena outside of their control such as the property boom and the resulting exodus of people, talent and business to the borough, and secondly through visionary leadership, policy, planning and action over time.

\section{CONCLUSION}

Changing a negative image requires a change in the product itself (Hankinson, 2004). Brooklyn could not have improved its image without substantial improvements to its product. The arts and culture will surely have contributed to the brand on all levels: emotional, intellectual, psychological and physical.

The most striking thing about Brooklyn's rebranding is the role that serendipity played in its success. Had artists moved to other boroughs or indeed to other cities when they were priced out of Manhattan, Brooklyn may not have had that special (and immeasurable) something that makes cities with a strong cultural offering so exciting and desirable. Had pioneering home buyers not followed and improved derelict residential property, Brooklyn's neighbourhoods might still be waiting for their renaissance. These two phenomena, sparked by a change in economic circumstances in Manhattan, were the turning point for Brooklyn. There was no policy designed specifically to attract these people to the borough. It was not the brainchild of a visionary leader. It was a city (or as Koolhaas would put it: an 'urban life-form') re-organising itself in response to economic change.

But this was only the start of Brooklyn's repositioning and it took visionary leadership, policy and purposeful activity to orchestrate its rebranding and this work continues today. The policies that the public and private sectors pursue impact on city brands. Across the board, and in particular in urban regeneration, policy drives activity that impacts how our cities look and feel, how we engage with them, what benefits they offer us and how we perceive them. In Brooklyn, responsive policy and leadership underpinned and built on activity and trends already happening in the community and that had the potential to shift perceptions of the borough. In establishing an environment where culture can flourish, Brooklyn 
established the means to reposition itself. The cultural community going about its daily business made a key contribution to rebranding Brooklyn.

While Brooklyn provides us with an exciting example of how the arts and culture can contribute to branding places, the question remains whether or not Brooklyn provides us with a model that can be duplicated in other places. Can more cities improve their brand by being more responsive to their resident artists and cultural activity? Are our city leaders and policy makers prepared to support the arts and culture without a guarantee of direct and measurable economic return? And what about cities with little cultural capital to build on? Is building a brand on culture achievable or desirable for these cities? Does it require a catalyst the scale of Frank Gehry and the Guggenheim to kick start the process?

Culture has become a key element in urban regeneration initiatives. In the UK, 'cultural quarters' are a part of many city master plans, but are they connected well enough and responsive to what is already happening in cultural communities? Are they building on the energy and vitality of the people who can make the master plan a success? Are leaders and developers brave enough to see beyond the bottom line? If they are, there is a good chance that negative images will be replaced with positive ones and perceptions will shift. If not, more negative images will be produced, reinforcing an already poor brand and create 'proof' that culture as a tool for regeneration does not work. In the Brooklyn example, culture works when it is part of a multi-layered and responsive approach to regeneration, when there is strong visionary leadership and follow-through and when a balance is struck between imported art and the local arts community, allowing for diversity and the unique creative character of a city to emerge and grow.

\section{Brenda Parkerson Special Issue Editor}

\section{Note}

1 Brooklyn Academy of Music (BAM) is a performing arts venue in Brooklyn, New York. It is known as a centre for progressive and avant garde performance. The BAM Local Development Corporation (BAM LDC) was a non-profit organisation whose mission was to create a vibrant, mixed-use multicultural arts district in Downtown Brooklyn. BAM and the BAM LDC were formally separate entities. However, the LDC was chaired by Harvey Lichtenstein, who was BAM's executive director for 32 years before founding the LDC in 1998. BAM LDC was moved under the umbrella of the Downtown Brooklyn Partnership in 2007.

\section{References}

Anholt, S. (2005) 'Nation brand as context and reputation', Place Branding, Vol. 1, No. 3, pp. 224-228.

CABE (2007) 'Brooklyn Academy of Music Cultural District, New York', Case Study. www.cabe.org.uk/default.aspx? contentitemid $=1272$.

De Chernatony, L. (1992) 'Categorising brands: Evolutionary processes underpinned by two key dimensions', Working Paper Series, City University Business School, January.

Hankinson, G. (2004) 'The brand images of tourism destinations: A study of saliency of organic images', Journal of Product and Brand Management, Vol. 13, No. 1, pp. 6-14

Kavaratzis, M. and Ashworth, G. J. (unpublished) 'Beneath catchy slogans: European cities as corporate brands'.

Koolhaas, R., as cited in Speaks, M. (2002) 'Individualization without identity city branding', NIA Publishers, Rotterdam, The Netherlands, pp. 20-31.

Lutfy, J. (2005) BAM Local Development Corporation, personal communication, 16 March.

Markowitz, M. (2007) Brooklyn Borough - State of the Borough Address. 1 February, Steiner Studios, Brooklyn Navy Yard. http://www.brooklyn-usa.org/Pages/State_of_ the_Borough/stateoftheborough.htm.

Parkerson, B. and Saunders, J. (2005) 'City branding: Can goods and services branding models be used to brand cities?' Place Branding, Vol. 1, No. 3, pp. 242-264.

Steigerwald, B. (2003) 'The steel city searches for a identity', Pittsburgh Tribune Review, 23 February, available at http:// www.pittsburghlive.com/x/tribune-review/specialreports/ enterprise2003/s_119125.html. 